\title{
THE FUNCTIONS OF ILLOCUTIONARY SPEECH ACTS USED BY TEACHERS IN THE CLASSROOM INTERACTIONS
}

\author{
Petra Armistany ${ }^{1}$ Zamzani $^{2}$
}

\author{
petra.armistany2016@student.uny.ac.id 1 \\ zamzani@uny.ac.id 2 \\ Universitas Negeri Yogyakarta \\ DIY, Indonesia
}

\begin{abstract}
This research aims to describe the functions of illocutionary speech actsused by teachers in learning interactions in class. The research method used in this study is qualitative descriptive. The data collection techniques in this study are observing and taking notes. The source of data in this study is teachers' speech acts in learning interactions at State Vocational High School (SMK Negeri) 1 Klaten. The data used is the teachers' oral speech on Mathematics, Science, History, and Accounting subjects in thelearning interactions at SMK Negeri 1 Klaten which has one conception or main idea. According to the results of the study, there are five functions of illocutionary speech acts used by the teacher in the learning interactionsin the class. The five functions include assertive functions in the form of stating and complaining; directive function in the form of commanding and advising; expressive function in the form of greeting and praising; commissive function in the form of promising and offering something; declarative function in the form of giving a name. Of the five functions, directive function is used most frequently, in which the teachers giving more commands.
\end{abstract}

Keywords: speech acts, illocution, learning interactions.

\section{INTRODUCTION}

A speech act is a study in the area of language philosophy. This study is based on an understanding of the context in each speech. The context is used to explain the speech or use of language used where with the context, the meaning of a speech will be easier to understand (Austin, 1975: 69-148). The success of speech acts is defined in the form of recognition of what the speakers convey by the audiences. It is proven by the existence of three types of actions that will occur when someone expresses their speech. First, locutionary acts that only describe actions to express something. Second, the illocutionary acts are to do something by saying something. Then, the perlocutionary are the acts related to the conclusion of something that is considered to be the effect left on the listener. These three varieties are interrelated because, in a speech, it is sure to have all three types of actions (Bach and Harnish, 1979: 3; Austin, 2009). In a social situation in society, the use of speech acts does not only stop at what is spoken by the speakers but also how the understanding possessed by the interlocutors. Even though there is only one word said like "Sorry!" to make an apology or a few words and sentences such as "Sorry I forgot your birthday. That just crossed my mind.", such actions will not be understood and accepted well if the interlocutors do not understand the cultural situation of the speakers (Milleret, 2007: 44). Grundlingh (2017: 2) stated that speech acts are significant in communication. Every time we communicate with other individuals, we (the speakers/writers and listeners/readers) will use words to convey the message and understand the message received. Parker (1986: 11) stated that when the context involved in certain speeches, the connotations and meaning associations that will be born tends to be numerous. Furthermore, if the 
context is close to social dimensions and cultural language, then it can be ascertained that the meaning to be born will also be more varied.

Zamzani (2007: 26) revealed that Indonesian society consists of various kinds of cultural backgrounds based on specific areas. Such conditions have an influence when they speak in Indonesian. When using Indonesian, the cultural elements of the area are attached to the speech they convey. Rahardi (2009: 36) explains the context is the environment in which the language entity is used. In this case, the environment can cover both the physical environment and the non-physical environment.

Teaching and learning activities are normative value interaction. It is a process that is carried out consciously and purposefully. The process is said to be successful if it can bring changes in the knowledge, skills, and attitudinal values in students (Djamarah, 2005: 12). As a structured system, the teaching and learning interactions contain several components which include goals, learning materials, teaching and learning activities, methods, tools, resources, evaluation, and language.

Wardhaugh (1972: 3) defined language as a system of sound symbols used for human communication. One of the functions is as a means of communication in teaching and learning interactions. In this case, the teachers' role is inseparable from the use of proper and correct language. They must be able to guide and attract the attention of students to be interested in participating in the teaching and learning activities. Huth (2011: 2) said that learning, including language learning, is seen as a problem that students have. At this stage, the socialization done by the teachers gradually becomes certain interactional practices from time to time. This practice forms an environment of interaction where the language used during learning and teaching must then be understood. The primary objective so far is to build a particular pattern between teachers and students. This interaction occurs because it is related to the activity and format of individual interactions in learning.

In learning interactions, teachers always use language to facilitate the interaction process. As a person, the teacher who has a vital role in learning activities uses more verbal speech as a medium to convey ideas to the students. Speech acts are essential in pragmatic studies. Speaking a specific utterance can be seen as taking action (influencing or asking). Pragmatic awareness can be obtained easily if a person is involved in a real performance where events occur as a natural consequence of human needs or preferences rather than just as a requirement in completing assignments or answering exam questions (Ifantidou, 2011: 333).

The context in speech acts is explained by Austin (1975: 69) in his book entitled How to Do Things with Words by describing that utterances cannot be given unless they are delivered in appropriate circumstances. Searle (1969: 54) agreed with Austin for the fact that speech acts have a final role or condition that must be fulfilled by the context.

The term context is defined by Mey (1993: 38) as an environmental situation in a broad sense that allows participants to interact and make their speech understandable. The close relationship between speech acts and context is a way in which context contributes to the actual speech acts. For example, whether social action is genuine and in what sense. One might assume if the concept of a context allows the person to describe the speech acts as social action that changes the context (Sbisa, 2002: $1)$.

This study aims to determine the type of illocutionary speech acts used by the teachers in the learning interactions in the class conducted at SMK Negeri 1 Klaten. Illocution can be considered as the most crucial action in the study and understanding of speech acts (Nadar, 2009: 14). This analysis is part of a qualitative descriptive study that raises the problem of speech acts, especially illocution, used by the teachers during the learning process in the class.

\section{RESEARCH METHODS}

The design used in this study is a descriptive qualitative approach. Creswell (2016: 4) defined qualitative research as a method to explore and understand meanings by some individuals or groups of people ascribed to social or humanitarian problems. This research is carried out by observing the ongoing learning process. The researcher focused on the main topic of the paper, namely explaining the illocutionary speech acts used 
by teachers in learning interactions at SMK Negeri 1 Klaten. The subjects in this study were the illocutionary speech acts used by the teachers found in Mathematics, Science, History, and Accounting subjects in teaching and learning interactions at SMK Negeri 1 Klaten. The object of the research is the conception or main ideas contained in the teachers' speech in the teaching and learning interaction at SMK Negeri 1 Klaten.

The source of data in this study is in the form of teachers' speech acts in learning interactions at SMK Negeri 1 Klaten. Data found in the learning interactions are used in the analysis. The data used is the teacher's oral speech on Mathematics, Science, History, and Accounting subjects in the interaction of learning at SMK Negeri 1 Klaten which has conception or main idea, so that more in-depth analysis can be carried out on the data. As Lofland and Lofland (1984: 47) have stated that the primary data sources in qualitative research are words and actions; the rest are additional data such as other documents.

The data collection techniques in this study used two types of techniques, including observing and taking notes techniques. The technique was carried out by listening to the teachers' speech acts in the learning interaction at SMK Negeri 1 Klaten. The taking notes technique is done by writing on the data card. The researcher used the data cards to record the research data to ease the grouping of the data.

The data analysis method used in this study is constant comparative or often called as the equivalent method. This method is done by connecting and comparing lingual and extralingual elements (Mahsun, 2006: 234-236). When the teachers delivered the speech acts in the learning interactions at SMK Negeri 1 Klaten, the researcher had begun to analyze the speech delivered by the teachers. In line with this opinion, Sugiyono (2015: 337) described that the activities in data analysis could be done in the following ways including by data reduction, data display, and conclusion drawing/verification. Data reduction is the obtained data from the field needs to be carefully recorded. Following the data reduction is the second step called data display. In this qualitative research, the presentation of data can be done in table form. Through the presentation of the data, the data is organized and arranged in a relationship pattern to make it easier to understand (Sugiyono, 2015: 343). Then, the third step in analyzing qualitative data is drawing conclusions and verification. The initial conclusions are still temporary and will be changed if no substantial evidence is found to support the next stage of the data collection. Thus, the conclusions in qualitative research may be able to answer the research problems formulated in the beginning, but maybe not, because the problems and formulation of the problem in qualitative research are still temporary and will develop after the research are done in the field (Sugiyono, 2015: 345).

\section{RESULTS AND DISCUSSION}

The results of this study indicate that there are five functions of illocutionary speech acts used by the teachers in the learning interactions. Those functions include assertive functions in the form of stating and complaining; directive function in the form of commanding and advising; expressive function in the form of greeting and praising; commissive function in the form of promising and offering something; declarative function in the form of giving a name. Of the five functions, the directive function is used most frequently. It can be seen in the following table.

Illocutionary speech acts used by teachers in the learning interaction in the class

\begin{tabular}{ccc}
\hline $\begin{array}{c}\text { Type of Speech } \\
\text { Acts }\end{array}$ & Functions & Total \\
\hline Illocutionary & Directive & 127 \\
\cline { 2 - 3 } & Assertive & 70 \\
\cline { 2 - 3 } & Commissive & 15 \\
\cline { 2 - 3 } & Expressive & 12 \\
\cline { 2 - 3 } & Declarative & 2 \\
\hline
\end{tabular}

The following is a discussion of the results of the analysis of the illocution used by the teachers in the learning interactions that takes place in the classroom.

\section{Directive Function}

The directive illocutionary act is intended to cause some effects through the actions of the listener. As for some directive speech functions delivered by the teachers in the learning interactions at SMK Negeri 1, Klaten is ordering, commanding, begging/asking, advising, and recommending. 
Directive speech acts in this study can be seen in the following data.

(1)

$\begin{aligned} \text { Guru } & : \begin{array}{l}\text { "Besok ulangan } \\ \text { hariannya ada dua. }\end{array} \\ \text { Siswa } & : \text { Silakan dari slidenya bu } \\ \text { Guru } & : \begin{array}{l}\text { guru kalian pelajari dari } \\ \text { buku paket juga." } \\ \text { "Bingung, bu." }\end{array} \\ & \text { "Bukannya sulit dipahami, } \\ \text { Siswa } \quad: & \text { tapi kalian itu nggak mau } \\ & \text { membaca. Buku paket ini } \\ & \text { kandel, karena memang } \\ & \text { banyak ceritanya, tidak } \\ & \text { langsung pada poin-poin. } \\ & \text { Makanya kalian itu } \\ & \text { memang harus gemar } \\ & \text { membaca." } \\ & \text { "Aaaaaa...." }\end{aligned}$

(Context: Delivered by the teacher when explaining a material used for a test. At the same time, the teacher ordered the students to learn some material that had been learned in the previous meetings and material from the notes.)

170/098/3/1/01082018

(2) Guru : "Yang kesulitan mana yang kesulitan? Yang belum bisa, angkat jarinya mana yang belum bisa! (guru meminta siswa untuk mengangkat jarinya)

(beberapa siswa mengangkat jari)

"Ayo mbak maju! Nomor 2A."

Siswa : "Saya, Bu?"

"Iya, kamu."

Guru :

Siswa :

Guru :

(Context: Delivered by the teacher when pointing and asking one of the students to work on the problem in the front.) 059/029/2/3/24072018

(3) Guru : "Ini nunggu temen-temen yang Siswa : di sana, apa dimulai duluan?"

Siswa : "Nunggu!"

Guru : "Ealah..nunggu terus!"

"Padune! Oya...kemarin sudah sampai mana?"

(Context: Delivered by the teacher when he/she began the learning activities by asking the last material ) 003/009/1/1/14052018

(4) Siswa : "Bu, dari belakang gentian, bu."

\begin{tabular}{|c|c|}
\hline Guru & "Apa?" \\
\hline Siswa & $\begin{array}{c}: \text { "Debatanya dari absen } \\
\text { yang belakang." }\end{array}$ \\
\hline Guru & $\begin{array}{l}\text { : “Kok ngatur bu Harlena... } \\
\text { Aaaaa... Kalau tidak mau } \\
\text { maju sesuai yang ibu } \\
\text { tunjuk ya sudah tidak } \\
\text { usah maju saja kamu!” }\end{array}$ \\
\hline
\end{tabular}

(Context: Delivered by the teacher when answering a question from a student. At the same time, the teacher rejected the request.)

$220 / 084 / 4 / 4 / 01082018$

\section{(5) Guru : "Hari Jumat nggak libur \\ Siswa : kan?" \\ (sambil tertawa) "Iya deh."}

(Context: Delivered by the teacher when recommending Friday as the day the teacher chose to carry out the test.)

017/053/1/1/14052018

Based on the context, speech (1) was delivered when the teacher explained a material used for a test. The speech is included in the type of directive illocution which functions to give a message or tell the students about the upcoming test with the material that has been studied at the previous meetings. At the same time, speech (1) requires answers from the listeners, in this case, are the students, to respond to what is delivered by the speaker or the teachers.

Based on the context, speech (2) was delivered when the teacher pointed and asked one of the students to work on the problem in the classroom when the teacher. The purpose of speech (2) is asking the students to do what the teacher wants. This objective is relevant to the function of directive speech namely commanding as conveyed by Sari (2016: 20) that directive speech is used by teachers to express commands directly to students to do something, and the students are required to carry out the commands immediately. A similar study was also conducted by Rahmayanti and Marlina (2018: 5) that confirms the present finding. In this study, the example is "oh come on Pascal, it is not so bad in there..". The context of the speech was that there was a character named Pascal who wanted to go out, but a character named Rapunzel rejected this. Therefore, Rapunzel made a statement ordering Pascal to stay where he was standing, the tower. 
Based on the context, speech (3) was delivered when the literacy activities in the morning in the class were over. The teacher and the students did a question and answer session with a rowdy class atmosphere because the learning activities had not begun. Then, the teacher asked the students in the class, whether learning can be started. However, they stated that it was better to wait for other students who had not yet entered the class. While waiting for other students, the teacher asked about the last material learned in the class. "Padune! Oyaa... kemarin sudah sampai mana?" The teacher asked the question to students using Indonesian with the insertion of Javanese in Indonesian, which means 'Alasan! Oyaa..kemarin sudah sampai di mana?'. The speech demands an answer or information from the students to do something by asking them to take out the textbook. Therefore, the speech is included in the type of directive illocution which functions to order.

Based on the context, speech (4) was delivered by the teacher when responding to a request by one of the students to him. Speech (4) contains a rejection delivered by the teacher to the student's request as well as serves to advise the student not to act disrespectfully. The results of the research are relevant to the results of a study conducted by Fenda Dina Puspita Sari (2016) which stated that directive speech which serves to give advice is the expression conveyed by the speakers so that the listeners acting in a better manner.

Based on the context, speech (5) was delivered by the teacher when recommending Friday as the day the teacher chose to carry out the test. The speech was delivered by the teacher and had a directive function of recommending because the school situation was not effective at that time by the frequent of empty hours. Therefore, this situation requires the teacher to look for another day to carry out the test. Besides recommending, Speech (5) also has a purpose to order so that the listeners do something according to the wishes of the speaker.

\section{Assertive Function}

This assertive illocution involves the speaker in the truth of the propositions expressed. The several functions of assertive speech contained in the teachers' speech in this study were carried out when the teachers were expressing, suggesting, complaining, and claiming. The speech often appears at the beginning of the learning activities, and when the teacher explains the lesson materials. The following are examples of assertive illocutionary speech acts used by the teachers in learning interactions at SMK Negeri 1 Klaten.

(6) Guru : "Kalau nyatet kan kemarin udah. Hari ini kita tinggal melanjutkan latihan yang kemarin itu tentang metode penilaian sistem."

Siswa : "Perpetua."

Guru : "Sistem perpetua? Masih inget nggak?"

Siswa : “Nggak!" (anak-anak menjawab dengan tertawa)

Guru : "Do lali kabeh?" (ekspresi kecewa)

Siswa : "Ealah."

(Context: Delivered by the teacher when asking about lesson material at the previous meeting.)

009/023/1/1/14052018

(7) Siswa : "Gimana niki bu?

Guru : "Piye hayoo? Garapen sikik. Wis isoh eksponen durung le? Dibuat eksponen perpangkatan dulu. Yang

Siswa : dipangkatke berapa?"

Guru : "Niki to, bu?"

"Dipindah satu ruas dulu

Siswa : aja, mbak."

"Yaa yaa saya tau bu."

(Context: Delivered by the teacher when helping a student who was working on a problem.)

$100 / 129 / 2 / 3 / 24072018$

(8) Guru : "Kalau nyatet kan kemarin udah. Hari ini kita tinggal melanjutkan latihan yang kemarin itu tentang metode

Siswa : penilaian sistem."

Guru : "Perpetua."

"Sistem perpetua? Masih inget

Siswa : nggak?"

Guru : "Nggak!"

"Do lali kabeh?"

(para siswa kemudian

Siswa : membuka buku)

"Ealah."

(Context: The teacher asked again about the material being discussed, but the 
students forgot, and they opened their books.)

(9)

\begin{tabular}{|c|c|c|}
\hline \multirow{11}{*}{ Guru } & \multirow[t]{11}{*}{ : } & teri sik mbok \\
\hline & & aoleki sik langsung \\
\hline & & intineto? Nek kalian itu \\
\hline & & sebenarnya gur malas \\
\hline & & membaca. Gur pengen \\
\hline & & $\begin{array}{l}\text { njaluk intine to? Nah, itu } \\
\text { tadi sudah bu guru kasih }\end{array}$ \\
\hline & & $\begin{array}{l}\text { intine. Tapi nggak ada } \\
\text { salahnya kalian membaca. }\end{array}$ \\
\hline & & $\begin{array}{ll}\text { Sekali membaca gpp, } \\
\text { asalkan }\end{array}$ \\
\hline & & $\begin{array}{l}\text { artine. Nek di sini ha } \\
\text { artion }\end{array}$ \\
\hline & & berapa sampai berapa \\
\hline & & Hal 8-22. Gur sitik Iho." \\
\hline
\end{tabular}

Siswa : "Banyak lho bu."

(Context: Delivered by the teacher when a student said that he was confused when asked to study.)

$172 / 102 / 3 / 1 / 01082018$

Speech (6) was delivered by the teacher when telling students that the activity to be studied that day was to continue working on the practice questions. Based on the context, the speech is included in the type of assertive illocution which functions to express or inform. Therefore, the students understand and know what they will learn next. The results of this study are consistent with the research carried out by Witek (2015: 23) in a study entitled "Linguistic under-determinacy: A view from speech act theory." In this study, Witek (2015: 23) gave an example of "Petrus is wealthy." The context occurred in the speech was a man named Tomi who told a woman named Ann about the financial problems that were being experienced by the man. Then, without thinking, Ann immediately answered with the statement, "Petrus is wealthy." In this context, the speech used an assertive type of illocutionary speech act that has a function to tell. According to the context, Ann wanted to tell that the person who will be able to help solve the problem faced by Tomi is Petrus.

Speech (7) was delivered by the teacher when a student asked about the question he was working on. The student felt difficulties and doubts about the answers he had done. Therefore, the teacher advised the student to keep working and giving directions about the steps in working on the problem. Speech (8) was delivered by the teacher to convey his disappointment or complaints to students who do not remember the material that has been studied at the previous meeting. The teacher conveyed his disappointment with the utterance "Do lali kabeh?", an utterance in Javanese, which means 'Kalian semua lupa?' In this context, this utterance is not only to convey a question to the students but also asking students to do something either with oral answers or with actions.

The teacher delivered a speech (9) in the context of a rowdy classroom because of the information provided by the teacher about the test. At the same time, the teacher conveyed speech that is considered to claim the habits of students when asked to study. One of the claims conveyed by the teacher to students' habits is feeling lazy to learn by not wanting to read textbooks. Students are used to just reading material summaries and do not want to read textbooks. This expression of speech is reinforced by the final speech delivered by the teacher, "Gur sithik, lho." It shows the impression of the claim given by the teacher that the material to learn is few, but the students are lazy.

\section{Commissive Function}

A commissive illocution is a speech act that involves the speaker on several future actions. The several functions of commissive speech in research are to promise and offer something. The following is some examples of the teachers' commissive illocutionary speech, which was found in the learning interaction at SMK Negeri 1 Klaten.

(10) Guru : "Soalnya apa itu kemarin bu guru udah janjian sama kelas samping kelas XII AK 2. Tapi

Siswa : hari ini nggak bawa laptop.

Guru : Terus sik siji wis dihapus. Wah iki koyone rung bayar spp ya." "Hello gaes!"

"Yaudah yaa, mau gimana

Siswa : lagi karena ada kesalahan. Jadi yowis tak janjeni minggu depan aja. Toh waktunya tinggal 15 menit. Karena waktunya tinggal 15 menit dan nanti buffering. 1 menit paling yo buffering-buffering, saiki materi aja. Materi selanjutnya yaitu adalah integrasi bangsa." 
"O $k$ bu."

(Context: Delivered by the teacher when he finally canceled watching the film.) $160 / 080 / 3 / 1 / 01082018$

(11) Guru : "Kowe rung isoh le? Nomor Siswa : 2?"

"Sampun kok bu. Nggen

Guru : kulo ndek wau ngeten niki."

Guru : (dengan ekspresi takut

Siswa : kurang meyakinkan)

Guru : "Yowis rapopo ayo nomor 2B!"

"Hhmm yang $\mathrm{C}$, siapa yang

C?"

"C sudah kok, bu."

"Lha yang kesulitan ii sik endi aku manut."

(Context: Delivered by the teacher when asking about the difficulties experienced by the students when working on a problem.)

061/034/2/3/24072018

Based on the context, speech (10) was delivered when the teacher was offering assistance to students to explain the material that was still considered difficult by students. At the same time, the speech performed by the teacher has the meaning to provide information so that the students become more aware of the material being studied. Based on the context, speech (11) was delivered when the teacher offered to help students work on practice questions that were still considered difficult. However, no students responded to what the teacher asked. Therefore, the teacher must repeat the question that has been communicated twice.

\section{Expressive function}

This expressive illocution has some functions to express, explain, or inform the psychological attitude of the speakers towards a statement of the state predicted by the illocution. The functions of expressive speech in the teachers' speech in this study were carried out when the teachers are delivering greetings, blaming, and praising. The following are some examples of the teachers' expressive illocution found in learning interactions at SMK Negeri 1 Klaten.

(12) Guru : "Assalammu'alaikum. Wr. Siswa : Wb."

"Wa'alaikumsalam. Wr. Wb."
(Context: Delivered when the teacher gave greetings when opening a learning activity.)

004/010/1/1/14052018

(13) Guru : "Selamat pagi."

Siswa : "Pagi bu." (menjawab dengan serempak)

(Context: Delivered when the teacher gave greetings at the beginning of a learning activity.)

044/001/2/3/24072018

$\begin{array}{lll}\text { Guru } & : & \text { "Plongah plongoh to? Rung } \\ & & \text { nonton to? } \\ \text { Siswa } & : & \text { Nah lho piye?" } \\ \text { Guru } & : & \text { "Udah." } \\ \text { Siswa } & : & \text { "Mulai dengan apa dulu? } \\ \text { Guru } & : & \text { Moderator ngapain?" } \\ \text { Siswa } & : & \text { "Moderator perkenalan } \\ \text { Guru } & : \text { dulu." } & \\ & \text { "Nah...berarti dalam } \\ & \text { keadaan posisi?" } \\ & \text { "Berdiri." } \\ & \text { "Iyaaakkk... S Silakan. } \\ & \text { Semuanya saya serahkan } \\ & \text { kepada Anda. Yo!" } \\ & \text { (siswa memperkenalkan } \\ & \text { diri) }\end{array}$

(Context: Delivered when the teacher commented on students who were less active in debating practice activities.)

195/036/4/4/01082018

(15) Siswa : "Bener ga e bu gini, bu?"

Guru : "Gimana? Ini punya siapa?"

Siswa : "Cicil.. kalau punyaku itu."

Guru : "Ini nanti pengerjaannya masing-masing tanggal di garis atas. Yang masih bingung sistem perpetual vivonya nanti tanya langsung ya. Jangan diem aja. Jadi, kalo misal kalian ke livo sama rata-rata bagi bisa langsung mengerti. Yak lanjutnya."

(Context: Delivered when the teacher looked at one of the student's correct answers on the board.)

036/118/1/1/14052018

(16) Guru : "Pokoknya kuncinya itu sabar. Dari langkah satu langkah dua dan seterusnya itu apa yang berubah itu harus jelas. Step by stepnya itu lho. Ooo... iki sik berubah, pangkate dipingke. Ooo...

Siswa : setelah pangkate dipingke 
$\begin{aligned} \text { Guru : } & \text { dadi apa, pangkate piro. Sing } \\ & \text { endi podo variabele. Nek } \\ & \text { sama nek dikalikan berarti } \\ & \text { pangkatnya ditambah, nek } \\ & \text { pembagian berarti } \\ & \text { pangkatnya dikurang, nek } \\ & \text { pangkat dipangkate meneh } \\ & \text { berarti pangkatnya dikali." } \\ & \text { "Dikali." } \\ & \text { "Gene pinter." }\end{aligned}$

(Context: Delivered when the teacher praised a student who continued the teacher's speech correctly.) 068/048/2/3/24072018

Based on the context, speech (12) was delivered when the teacher started the learning activity by greeting the students. The greeting is also expected to attract the attention of students in the class. Therefore, the speech is included in a type of expressive illocution which functions to greet. Based on the context, speech (13) was delivered when the teacher started the learning activity. The type of the illocution of the speech is an expressive speech and has a function of attracting the attention of the students who are still doing other activities outside the learning activities that should be conducted in the classroom.

This analysis corresponds to a research conducted by Emmiyati (2017: 103).

Gabrielle: "Hi."

'Hi.'

Gil: "Hi, I know you - the girl at the flea market."

'Hi, aku mengenalmu - gadis pasar loak.'

The context that occurred in the example is when Gil met Gabriella on the road. Then, Gil delivered expressive actions by giving a greeting.

Based on the context, speech (14) based on context has the intention of driving students who make a mistake when the practice of debate takes place. Students who are reprimanded by the teacher are silent and do not comment. Based on the context, speech (15) occurred when the teacher was correcting some answers from students written on the board. Then, the teacher stopped on one of the correct and useful answers. Therefore, indirectly, the teacher's speech has the intention to praise students. Based on the context, speech (16) occurred when one student answered the question correctly from the teacher. Then the teacher immediately said, "Gene pinter" which in English can be interpreted as 'Buktinya pintar.' and in this case, it is used to praise the student.

\section{Declarative Function}

Declarative illocution is a form of speech that connects the contents of speech with reality. The several functions of declarative speech contained in the teachers' speech in this study were carried out when the teacher was giving up and giving a name.

(17) Guru : "He'em. Yo. Ada kesulitan

$\begin{array}{lll}\text { Siswa } & : & \text { nggak?" } \\ \text { Guru } & : & \text { "Ada." } \\ \text { Siswa } & : & \text { "Yang mana?" } \\ \text { Guru } & : & \text { "Semua." } \quad \text { (anak-anak } \\ \text { Siswa } & : & \text { menjawab } \\ \text { Guru } & : & \text { serempak) } \\ \text { Siswa } & \text { : } & \text { "Yang mana?" } \\ & & \text { "Semua." } \\ & \text { "Lha semua? Yowis mulih } \\ & \text { wae rasah sekolah." } \\ & \text { "Horeeee... mulih...!"(anak- } \\ & \text { anak tertawa) }\end{array}$

(Context: Delivered by the teacher when the students felt that all questions were challenging to work on) 057/025/2/3/24072018
(18) Guru : "Sebentar...
Siswa : neng..nengnong..."
Guru : "Iya bu..."
"Bu Harlena masih duduk sini kok."

(Context: Delivered by the teacher when the lesson was over. When one of the students was in a hurry to leave the classroom, the teacher rebuked using another nickname.)

$$
227 / 140 / 4 / 4 / 01082018
$$

Speech (17) was delivered by the teacher when the classroom atmosphere began to be rowdy during the quite hot day. The teacher asked about the difficulties experienced by students. However, some of the students said that all the practice questions were difficult, and they did not want to work on them. Then, with a helpless expression or resignation, the teacher said, "Lha semua? Yowis mulih wae rasah sekolah." at the same time, to attract the attention of the students. Speech (18) was delivered by the teacher when he would end the learning activities in the class. Before leaving the classroom, the teacher tidied up 
some books first, but one of the students was in a hurry to leave the classroom. Then, the teacher called her by a nickname, "Neng ... nengnong."The speech is identified as a declarative illocutionary speech act that serves to give a name.

The findings of this study are relevant to the research conducted by Nuri Emmiyati and Indriani in an article entitled "Illocutionary Acts in 'Midnight in Paris' Movie." In this study, there is a form of illocution of naming or giving a name between two people named Zelda and Gil.

$\begin{array}{ll}\text { Zelda } \quad \text { : } & \text { “What do you do?" } \\ \text { Gil } & \text { 'Apa yang kamu kerjakan?' } \\ \text { Zelda } \quad \text { “Oh, I - I am a writer." } & \text { 'Oh saya - saya seorang penulis.' } \\ & \text { "What do you write? I know what } \\ & \text { you are thinking - This is boring - I } \\ & \text { agree - I'm ready to move on - let us } \\ & \text { do Bricktop's, Scott. I'm bored, and } \\ & \text { he's bored, we are all bored." } \\ & \text { 'Apa yang Anda tulis? Saya tahu } \\ & \text { apa yang Anda pikirkan - Ini } \\ & \text { membosankan - saya setuju - saya } \\ & \text { siap untuk melanjutkan - mari } \\ & \text { lakukan Bricktop, Scott. Aku } \\ & \text { bosan, dia bosan, kita semua } \\ & \text { bosan. ' }\end{array}$

In a speech delivered by Gil to answer the question from Zelda, he made a naming declaration. That was done by Gil when he introduced himself to Zelda. Gil said that he was a writer.

\section{CONCLUSION}

Based on the results of the data analysis of illocutionary speech acts used by the teachers in the learning interactions at SMK Negeri 1 Klaten, there are five functions found. The five functions are directive, assertive, expressive, commissive, and declarative.

Based on the conclusions above, the researcher recommends some suggestions for the development of better learning. (1) With the results of this study, it is expected that teachers can maintain speech acts that have been used in the learning process and require students to be more active. One type of speech that must be maintained is directive speech. (2) With the results of this study, it is expected that teachers can use more directive functions so that they require students to think actively in finding answers and answering questions from the teacher. (3) With the results of this study, it is expected that the results can be considered by the next researchers who will review speech acts. In this case, the results of the research can be used as materials, guidelines, information, or comparable material to other studies.

\section{REFERENCES}

Austin, J. L. (1975). How to do thing with words. Oxford: Oxford University Press

Austin, J. L. (2009). Soylemek ve yapmak. R. Levent Aysever, Trans. Istanbul: Metis.

Bach, K. and Harnish, R. (1979). Linguistic communication and speech acts, Cambridge, Mass.: MIT Press.

Creswell, J.W. (2014). Research design, qualitative, quantitative, and mixed methods approaches, fourth edition. Sage Publication.

Djamarah, Syaiful Bahri. Guru dan siswa dalam interaksi edukatif. Jakarta: Rineka Cipta.

Emmiyati, Nuri. (2017) Illocutionary Acts In "Midnight In Paris" Movie. English and Literature Department, Faculty of Adab and Humanities: Alauddin State Islamic University of Makassar. Journal UIN Alauddin. Retrieved from http://journal.uinalauddin.ac.id/ index.php/elite/article/download/3385/3192

Grundlingh, L. (2017). Memes as speech acts. Journal of Social Semiotics Vol 28, No 2 Page 147-168. Retrieved from http://dx.doi.org/10.1080/10350330.2017.1303020 
Huth, Thorsten. (2011). Conversation analysis and language classroom discourse.Journal Language and Linguistisc Compass Vol 5, No 5. Retrieved fromhttp://onlinelibrary.wiley. com/ wol1/doi/10.1111/j.1749818X.2011.00277x/full

Ifantidou, E. (2011). Genres and pragmatic competence. Journal of Pragmatics, 43,.327346. Retrieved from https://www.sciencedirect.com/science/journal/03782166/43/1

Lofland, John\&Lyn H.Lofland. (1984). Analysing social settings: a guide to qualitative observation and analysis, Belmont. Cal: Wadsworth Publishing Company.

Mahsun. 2005. Metode Penelitian Bahasa: Tahap Strategi, Metode, dan Tekniknya. Jakarta : Rajawali Pers.

Mey, Jacob L. (2004). Pragmatic an introduction. USA: Blackwell Publishing

Milleret, Margo. (2007). Teaching speech acts. Journal of the Council of Less Commonly Taught Languages. Retrieved from http://www.ncolctl.org/ files/Teaching-speech-act.pdf.

Nadar, Franciscus Xaverius. (2009). Pragmatik dan penelitian pragmatik. Yogyakarta: Graha Ilmu.

Parker. Frank. (1986). Linguistics for Non-Linguists. Little, Brown and Company: University of California.

Rahardi.Kunjana. (2009). Sosiopragmatik. Jakarta: Erlangga.

Sari, F.D.P. (2013). Tindak Tutur dan Fungsi Tuturan Ekspresif dalam Acara Galau Nite di Metro TV: Suatu Kajian Pragmatik. Skriptorium: Journal Universitas Airlangga, 1(2), 1-14. Retrieved from http://www.journal.unair.ac.id/download-fullpapers scriptorium882d24b 95efull.pdf

Sbisa, Marina. (2002). Speech acts in context. Journal Language \& Communication, 22, 421-436. Retrieved from http://www.elsevier.com/ locate/langcom.

Searle, John R. (1969). Speech acts. An essay in the philosophy of language. Cambridge: Cambridge University Press.

Sugiyono. 2015. Metode Penelitian Pendidikan (Pendekatan Kuantitatif,Kualitatif dan R\&D). Penerbit CV. Alfabeta: Bandung.

Wardhaugh, Roland. (1972). Introduction to linguistics. New York: McGraw-Hill Inc.

Witek, Maciej. (2015). Linguistic underdeterminacy: a view from speech act theory. Journal of Pragmatics, Volume 76. Retrieved from https://philpap ers.org/rec/WITLUA

Zamzani. (2007). Kajian sosiopragmatik. Cipta Pustaka: Yogyakarta. 